\title{
The effect of microencapsulated essential oils on the initial growth of maize (Zea mays) and common weeds (Echinochloa crus-galli and Chenopodium album)
}

\author{
Wpływ mikrokapsułkowanych olejków eterycznych \\ na początkowy wzrost kukurydzy (Zea mays) \\ i chwastów (Echinochloa crus-galli i Chenopodium album)
}

\author{
Agnieszka Synowiec ${ }^{1}{ }^{*}$, Aleksandra Smęda ${ }^{1}$, Janusz Adamiec $^{2}$, Danuta Kalemba ${ }^{3}$
}

\begin{abstract}
Summary
The aim of the study was to determine the effect of soil-maltodextrin (MDX) and MDX microencapsulated essential oils (EOs, 12\%) of peppermint (Mentha $\times$ piperita L.), caraway (Carum carvi L.) or calamus (Acorus calamus L.) at various doses (0.75, 1.5 and $3 \mathrm{~g} / \mathrm{pot}$ ), on the initial growth of maize (Zea mays L.), barnyard grass [Echinochloa crus-galli (L.) P. Beauv.] and lambsquarters (Chenopodium album L.). The results of a pot experiment showed the strongest inhibitory effect on the growth of the studied plants of MDX alone. Both the MDX and microencapsulated EOs decreased the relative chlorophyll content of the leaves in maize. Maize was the most tolerant to the microencapsulated EOs while lambsquarters was more sensitive to the microcapsules compared to barnyard grass. The highest doses of microencapsulated EOs, particularly those containing peppermint or caraway, caused the greatest decrease in the number and dry weight of the weeds. Based on the results, it can be concluded that the microencapsulated EOs pose a phytotoxic effect against weeds and should be studied further under field conditions.
\end{abstract}

Key words: barnyard grass; lambsquarters; phytotoxicity; growth inhibition; essential oils; maltodextrin

\section{Streszczenie}

Celem badań było określenie wpływu mikrokapsułkowanych w maltodekstrynie olejków eterycznych z mięty (Mentha × piperita L.), kminku (Carum carvi L.) i tataraku (Acorus calamus L.) oraz samej maltodekstryny na początkowy wzrost kukurydzy (Zea mays L.), chwastnicy jednostronnej [Echinochloa crus-galli (L.) P. Beauv.] i komosy białej (Chenopodium album L.). Preparaty dodawano w różnych dawkach do gleby. $W$ efekcie doświadczenia wazonowego stwierdzono, że wszystkie preparaty wywoływały silny efekt hamujący początkowy wzrost badanych roślin, a najsilniej działała maltodekstyna bez dodatku olejków eterycznych. Kukurydza była najbardziej tolerancyjna, a komosa najbardziej wrażliwa na zastosowane preparaty. U kukurydzy maltodekstryna i mikrokapsułkowane olejki powodowały spadek względnej zawartości chlorofilu w liściach. Najwyższa dawka mikrokapsułkowanych olejków eterycznych, szczególnie z dodatkiem olejku z mięty lub kminku, powodowała największe ograniczenie liczby i suchej masy badanych chwastów. Podsumowując należy stwierdzić, że mikrokapsułkowane olejki eteryczne wpływają hamująco na początkowy wzrost chwastów i powinny być badane w warunkach polowych.

Słowa kluczowe: chwastnica jednostronna; komosa biała; fitotoksyczność; zahamowanie wzrostu; olejki eteryczne; maltodekstryna

\footnotetext{
${ }^{1}$ Department of Agrotechnology and Agricultural Ecology

Faculty of Agriculture and Economics, University of Agriculture in Krakow

Al. Mickiewicza 21, 31-120 Kraków

${ }^{2}$ Faculty of Process and Environmental Engineering, Lodz University of Technology

${ }^{3}$ Faculty of Biotechnology and Food Sciences, Institute of General Food Chemistry

Lodz University of Technology

Wólczańska 171, 90-924 Łódź

*corresponding author: a.stoklosa@ur.krakow.pl
} 


\section{Wstęp / Introduction}

Essential oils (EOs) have shown to be strong inhibitors of weed germination in several in vitro evaluations (Rolli et al. 2014; Synowiec et al. 2016). Furthermore, Cavalieri and Caporali (2010) showed that EOs inhibit seed germination when applied to the soil surface. However, because of their high volatility and low water solubility, the wider environmental uses of EOs is restricted. Additionally, EOs are difficult to disperse homogeneously in soil. These barriers may be overcome by the process of microencapsulation (Ré 1998), which slows down the release of the enclosed oils, whilst retaining their biological properties, thereby extending their efficacy (Nazarro et al. 2012). Investigations of the fungicidal and bactericidal potential of EOs have shown that microencapsulation retained the antimicrobial activity and improved the stability of oregano oil (Arana-Sanchez et al. 2010; da Costa et al. 2012; Hernández-Hernández et al. 2014), and thyme oil (Del Toro-Sanchez et al. 2010), and enhanced the antibacterial activity of lavandin oil (Varona et al. 2013). There is a paucity of studies verifying the biological action of EOs against weeds. Previously, Scarfato et al. (2007) studied the effect of EO vapors emitted from polyurea microcapsules, in Petri dishes containing sage, lemon balm, lavender or thyme oils, on the germination of radish, lettuce and watercress seeds. The authors observed that microcapsules containing a thyme EO core, inhibited germination of all the tested species, whereas the microcapsules with lavender EO stimulated germination of lettuce and garden cress.

Spray-drying is the most common and cost-effective technology to produce microencapsulated food materials. Maltodextrins (MDXs) are considered effective encapsulating agents because they exhibit low viscosities at high solid content and show good water solubility (Katz 1986). They are often used in combination with other materials, such as gums that improve the microencapsulation efficiency (Gharsallaoui et al. 2007).

Previously, we showed a strong inhibitory potential of both peppermint and caraway EOs and a medium effect of calamus EO on the germination of barnyard grass [Echinochloa crus-galli (L.) P. Beauv.] and lambsquarters (Chenopodium album L.) seeds and a considerably less efficacy of these oils against maize (Zea mays L.) kernel germination (Synowiec et al. 2016). The current study aimed to measure the phytotoxic effect of these EOs, microencapsulated with MDX as the carrier, on the initial growth of maize and both E. crus-galli and Ch. album weed species. We hypothesize that microencapsulation will provide a comparable or improved biological efficacy of the EOs due to their slow release from the microcapsules. As emphasized by Terzi (2008), in the context of biological interactions, the dwell time of the bioactive compound donor is crucial; the longer the more effective.

\section{Materiały i metody / Materials and methods}

\section{Olejki eteryczne / Essential oils}

In this study, seeds of caraway (Carum carvi L.), peppermint herb (Mentha $\times$ piperita L.) and calamus rhizomes (Acorus calamus L.) were used as the EO sources. Caraway and calamus oils were purchased from HerbaNordPol-Gdańsk Sp. z o. o. (Gdańsk, PL) and microencapsulated in the laboratory. Microencapsulated peppermint oil was kindly supplied by Hoffmann Wytwórnia Aromatów Spożywczych (Zamysłowo, PL).

\section{Mikrokapsułkowanie olejków eterycznych / Microencapsulation of essential oils}

The microencapsulated EOs were prepared by a twostep process, whereby an oil-in-water emulsion was subsequently spray-dried. Commercial MDX from potato starch (Nowamyl, PL) and gum arabic were used as carrier materials. MDX, gum arabic and water were mixed in the ratio 30:70 (v/v). EO and Tween 180 were added at 13 and $0.1 \mathrm{wt} \%$ of the carriers, respectively. The mixture was then homogenized for 20 minutes at full sonicator power using a UP200S ultrasound homogenizer (IKA, Dr Hielscher $\mathrm{GmbH}$, Berlin, Germany) equipped with a $14 \mathrm{~mm}$ diameter impulse generator. Next, the emulsion was spray-dried (Soottitantawat et al. 2003), using a mini spray dryer B-290 (Büchi, Switzerland) at inlet and outlet temperatures of 160 and $80^{\circ} \mathrm{C}\left( \pm 1^{\circ} \mathrm{C}\right)$, respectively.

\section{Zawartość i skład olejków eterycznych w mikrokapsułkach / Content ad composition of essential oils in microencapsulated product}

The spray-dried microcapsules $(20 \mathrm{~g})$ and water $(60 \mathrm{ml})$ were hydrodistilled for 3 hours using Clevenger-type apparatus. The volume of separated oil was multiplied by the specific density of the powder, which was determined by the pycnometer method.

The chemical composition of the EOs was analyzed by gas chromatography-mass spectrometry (GC-MS) using a Trace GC Ultra apparatus (Thermo Electron Corporation, Milan, Italy) equipped with a flame ionization detector (FID) and MS DSQ II detector. A simultaneous GC-MS/FID analysis was performed using an MS-FID splitter (SGE, Analytical Science). The operating conditions were as follows: apolar capillary column Rtx$1 \mathrm{~ms}$ (Restek), $60 \mathrm{~m} \times 0.25 \mathrm{~mm}$ i.d., film thickness $0.25 \mu \mathrm{m}$; temperature program, $50-310^{\circ} \mathrm{C}$ at $4^{\circ} \mathrm{C} / \mathrm{min}$; SSL injector temperature $280^{\circ} \mathrm{C}$; FID detector temperature $300^{\circ} \mathrm{C}$; split ratio 1:20; helium carrier gas at $300 \mathrm{kPa}$ pressure. Mass spectra were acquired over the mass range 30-400 Da, ionization voltage $70 \mathrm{eV}$ and ion source temperature of $200^{\circ} \mathrm{C}$. Identification of the components was based on a comparison of their MS data and retention indices (RIs) with data stored in the computer libraries, NIST 98.1, Wiley 275.1, and MassFinder 4.1. The RIs were determined according to a homologous series of alkanes $\left(\mathrm{C}_{8}-\mathrm{C}_{26}\right)$ analyzed under the same conditions with linear interpolation. Percentages were obtained from the FID response without the use of correction factors (Kalemba et al. 2001).

\section{Doświadczenie wazonowe / Pot experiment}

A pot experiment was established on the 7th May 2013, in a foil tunnel (no regulation of light or temperature), as 
a completely randomized design, with three replications (pots). Pots of $15 \mathrm{~cm}$ diameter and 11 volume were filled with a soil substrate composed of potting mix and sand in a 2:1 ratio. The pots were watered intensively and set aside for 2 days. Next, the microcapsules were spread on the surface of each pot and shallowly (ca. $1 \mathrm{~cm}$ deep) mixed with the soil substrate. The microcapsules were added to the pots at $0.75,1.5$ and $3 \mathrm{~g}$ per pot (equivalent to 50,100 and $200 \mathrm{~kg} / \mathrm{ha}$ and 6, 12 and $24 \mathrm{~kg} / \mathrm{ha}$ of each EO). Two control treatments were used, with pots containing 1) the soil substrate only and 2) the soil substrate with MDX at doses equivalent to 50,100 and $200 \mathrm{~kg} / \mathrm{ha}$.

On the same day that the microcapsules were applied to the soil, 7 seeds of maize cultivar Wilga and 12 seeds of E. crus-galli or Ch. album were sown into separate pots. The pots were watered on the 3rd day following sowing and subsequently watered according to the plant needs. On the 16th of May 2013, the pots were transferred outdoors. During plant growth, the relative content of chlorophyll in maize leaves (at the 3-4 leaves stage) was measured by SPAD-502 Konica-Minolta. The experiment was terminated on the 28th of June 2013. On that day, the plants in each pot were counted and cut at the soil level. The dry mass of the aboveground parts of the maize and weeds, respectively, and the mass of the maize roots was measured after drying at $50^{\circ} \mathrm{C}$ for 3 days.

\section{Analiza statystyczna / Statistical analyses}

The results were statistically analyzed by ANOVA for a completely randomized design. The means were separated by Tukey's test at $p=0.05$. All the analyses were performed using STATISTICA v. 10.0 software (StatSoft Inc. 2011).

\section{Wyniki i dyskusja / Results and discussion}

The analysis showed that the caraway microcapsules contained $12 \%$ EO, whilst the calamus and peppermint microcapsules contained 12.4 and $12.5 \%$ EO, respectively. The chemical composition of caraway and calamus oils recovered from the microcapsules was similar to that of their respective pure oils (Synowiec et al. 2016). The main constituents of caraway EO were carvone (63.2\%) and limonene $(34.8 \%)$, whilst calamus EO contained mostly acorenone $(5.5 \%)$, shyobunone $(5.7 \%)$, camphor $(6.6 \%)$ and camphene $(13.6 \%)$. The main constituents of the microencapsulated peppermint oil were menthol $(42.7 \%)$ and menthone $(26.5 \%)$.

The microcapsules influenced the growth of both maize and weeds but to different extents, which were mostly dose-dependent. Interestingly, the MDX alone displayed a strong and dose-dependent inhibitory effect against all the tested plants. In the soil, MDX could have indirectly, negatively affected the plants in two ways. First, as a source of carbon for soil microorganisms, MDX could increase their number and those microorganisms could pose a negative effect on the growing plants by intensifying nutrient consumption from the soil substrate. Second, we hypothesize that MDX could increase the soil extract concentration, decreasing the water uptake by the roots of the plants. In lettuce (Lactuca sativa L.), Rưžek et al. (2015) observed that a small $(1 \mathrm{~g} / \mathrm{l})$ addition of MDX to the green compost, composed from finely crushed green municipal waste, white high-moor peat, clayey soil from excavation, and pearlite, significantly improved the aboveground physiological parameters of lettuce growth, compared to green compost without MDX. This may suggest that both the soil type and MDX dose, cause distinct growth effects, depending also on the tested plant species.

Among the plant species, maize was the most tolerant to the majority of the tested microcapsules. Growth in the presence of microcapsules caused significant changes in the relative chlorophyll content in the maize leaves. At the highest doses, all the microcapsules decreased chlorophyll content (Fig. 1A). This reflects the stress that the applied microcapsules caused to the plants, due to the potential decrease in water uptake by roots and probable decrease in photosynthesis rate, given its strict correlation to chlorophyll content (Buttery and Buzzell 1977). Although the microcapsules did not influence the number of maize plants, they affected their biomass (Fig. 1B, C). The maize shoots were significantly less sensitive to the microcapsules compared to the roots $(p=0.04)$, as reflected by the decrease in the dry mass of the roots (Fig. 1B). The maize shoots were tolerant to all doses of the MDX alone and microencapsulated peppermint oil. In contrast, the dry mass of maize roots was significantly lower in the presence of all the microcapsules, particularly at their highest doses (Fig. 1C). Interestingly, the microcapsules with caraway and peppermint oils decreased the dry mass of the maize roots more than the MDX and microencapsulated calamus oil.

Both barnyard grass and maize belong to the Panicoideae subfamily however, E. crus-galli was much more sensitive to the microcapsules compared to maize (Fig. 2). The number of barnyard grass plants was significantly lower in the pots following MDX application, with approximately $55 \%$ fewer plants at the highest MDX dose compared to the control. Interestingly, almost inevitably the microencapsulated EOs caused a less pronounced inhibitory effect than MDX, except at the highest dose of peppermint EO $(200 \mathrm{~kg} / \mathrm{ha})$, which decreased the number of barnyard grass plants to five per pot, as similarly noted for the MDX. The other microencapsulated EOs either did not decrease the number of plants (calamus) or their effect was ambiguous (caraway) (Fig. 2A). Although the barnyard grass dry mass was decreased, this effect was statistically insignificant (Fig. 2B). Higher phytotoxicity of MDX in comparison to microencapsulated EOs is an interesting phenomenon that requires further research to elucidate. 
A

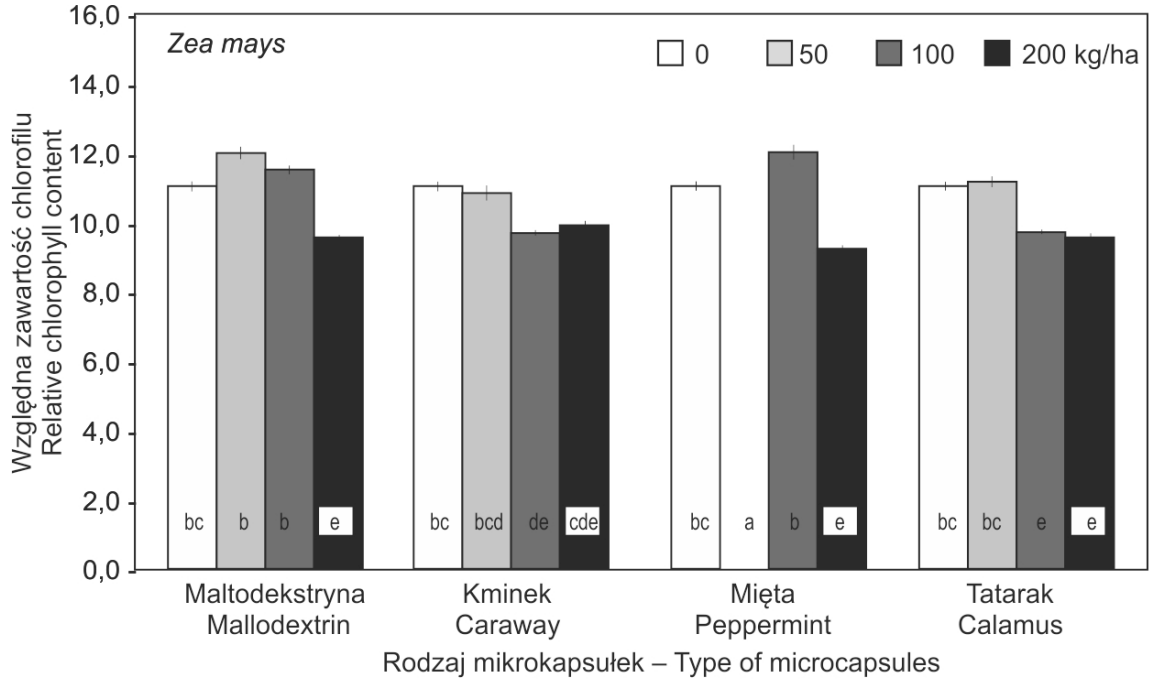

B

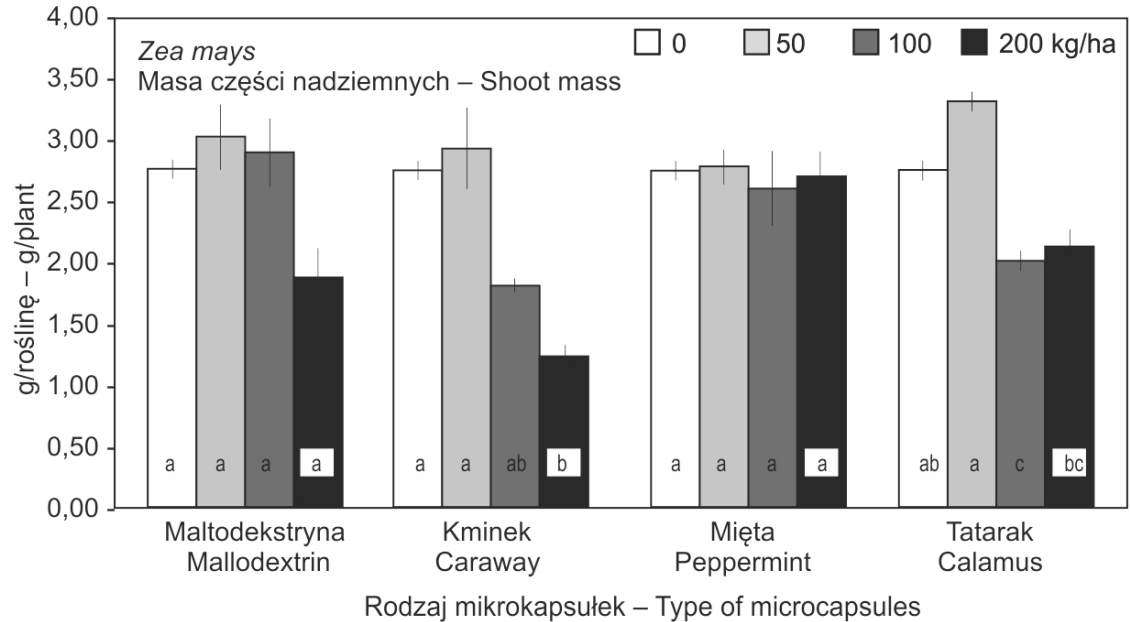

C

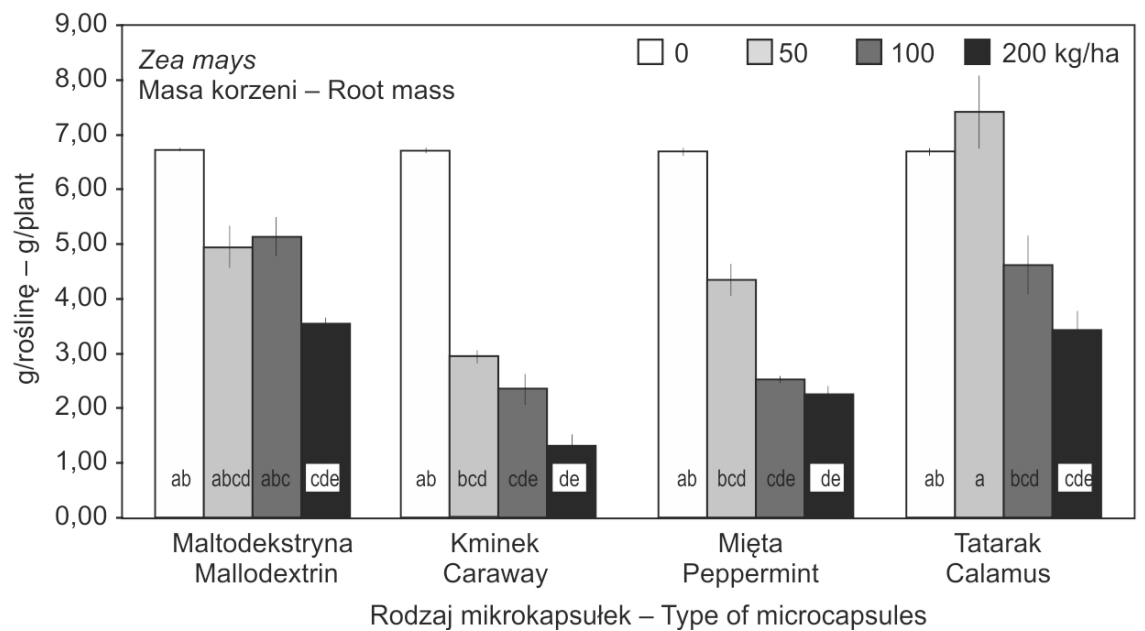

Rys. 1. Względna zawartość chlorofilu (A) i sucha masa części nadziemnych (B) oraz korzeni (C) kukurydzy rosnącej w obecności mikrokapsułek z olejkami eterycznymi. Obiekt kontrolny nie zawierał mikrokapsułek. Słupki prezentują wartość średnią \pm SE; $\mathrm{n}=3$. Różne litery oznaczają istotne różnice między obiektami, zgodnie $\mathrm{z}$ testem Tukeya przy $\alpha<0,05$

Fig. 1. A relative chlorophyll content (A) and a dry mass of maize shoots (B) and roots (C) growing in the presence of maltodextrin microcapsules with the studied essential oils. The control treatment (open bar) did not contain microcapsules. Bars present a mean value $\pm S E ; n=3$. Different letters indicate significant differences between means at $p<0.05$ according to Tukey post-hoc test 

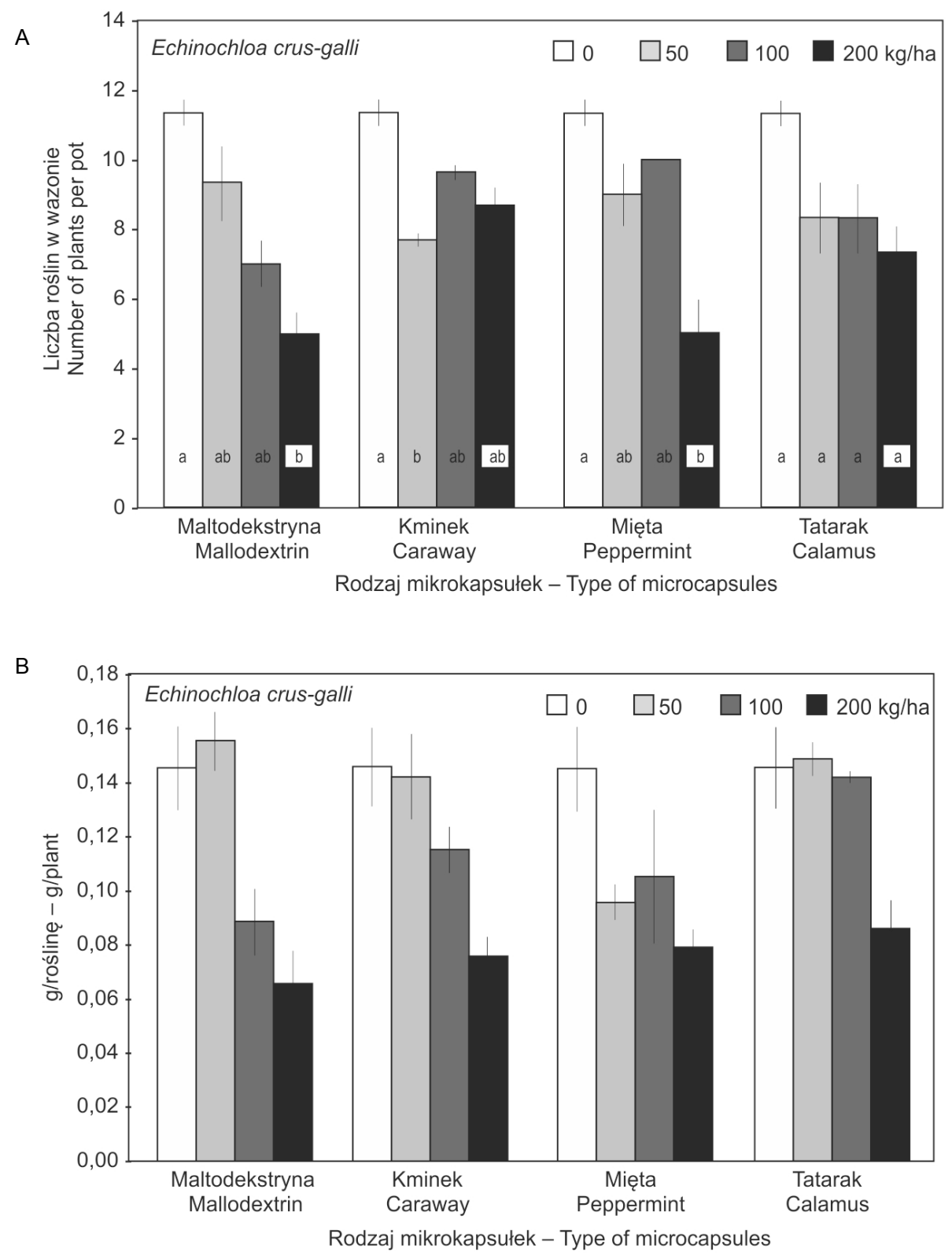

Rys. 2. Liczba roślin (A) i masa części nadziemnych (B) chwastnicy jednostronnej rosnącej w obecności mikrokapsułek z olejkami eterycznymi. Obiekt kontrolny nie zawierał mikrokapsułek. Słupki prezentują wartość średnią \pm SE; $n=3$. Różne litery oznaczają istotne różnice między obiektami, zgodnie z testem Tukeya przy $\alpha<0,05$

Fig. 2. Number of plants (A) and a dry mass of aboveground parts (B) of Echinochloa crus-galli growing in the presence of maltodextrin microcapsules with the studied essential oils. The control treatment (open bar) did not contain microcapsules. Bars present a mean value \pm SE; $n=3$. Different letters indicate significant differences between means at $\mathrm{p}<0.05$ according to Tukey post-hoc test

Lambsquarters was the most sensitive to the microcapsules in the soil substrate (Fig. 3). As shown by Synowiec and Drozdek (2016), dicotyledonous weeds are more susceptible to EOs than monocotyledonous ones. Compared to the control (no microcapsules added to the soil), the caraway microcapsules caused a higher decrease in the number of lambsquarters $(62.5 \%)$. MDX and the microencapsulated peppermint oil were slightly less effective. There was a lower number of lambsquarters plants in the soil containing peppermint microcapsules, compared to MDX alone but only at the two highest doses of the microcapsules. The influence of calamus microcapsules on the number of lambsquarters plants was not statistically significant (Fig. 3A). Analysis of lambsquarters dry mass revealed that MDX was the most inhibitory and this effect was dose-dependent, despite being non-significant (Fig. 3B). However, a significant decrease in lambsquarters dry mass was recorded for all the microencapsulated EOs, compared to the control, with an average decrease of 69,58 and $71 \%$, for caraway, peppermint and calamus microcapsules, respectively (Fig. 3B). 

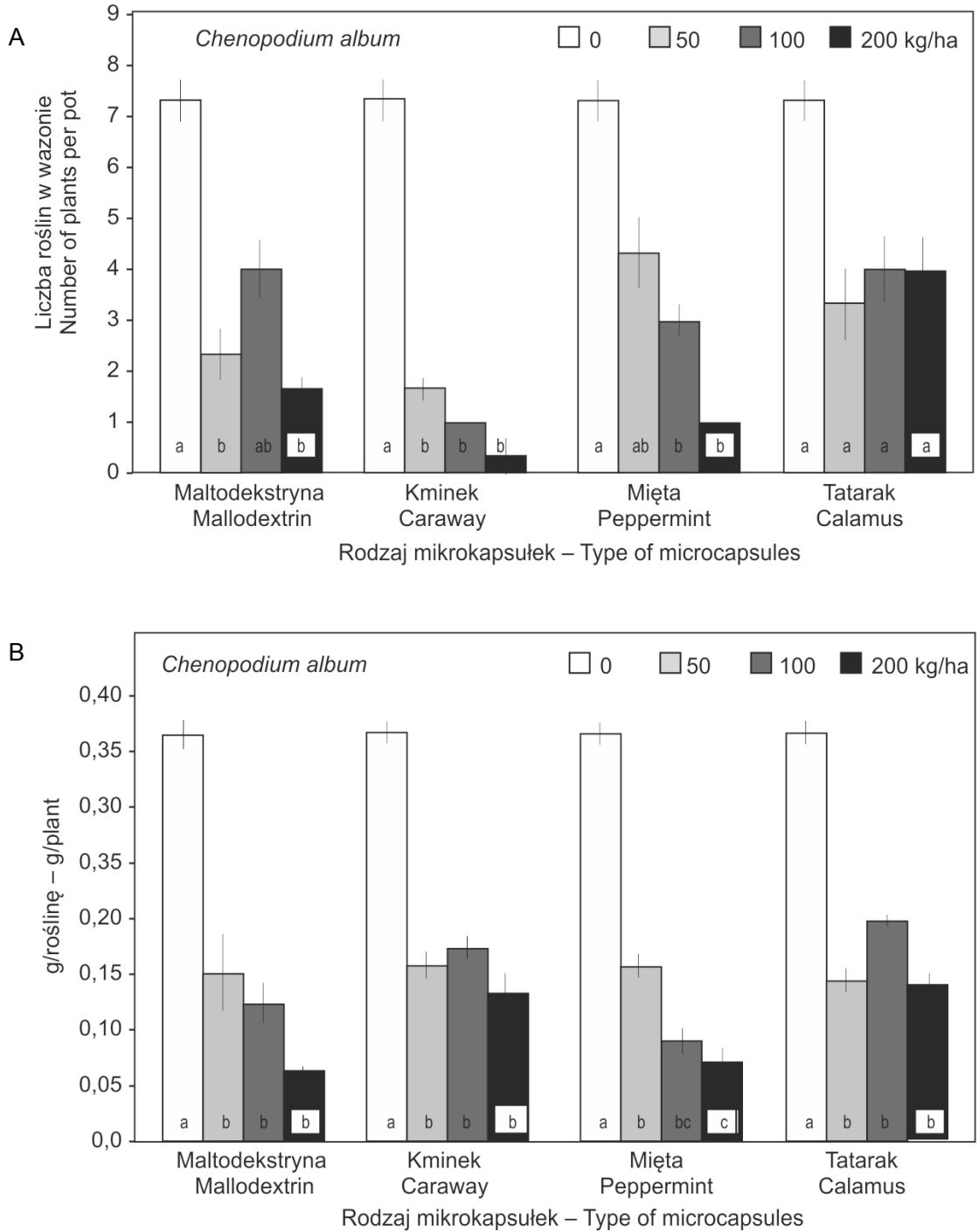

Rys. 3. Liczba roślin (A) i masa części nadziemnych (B) komosy białej rosnącej w obecności mikrokapsułek z olejkami eterycznymi. Obiekt kontrolny nie zawierał mikrokapsułek. Słupki prezentują wartość średnią $\pm S E ; n=3$. Różne litery oznaczają istotne różnice między obiektami, zgodnie $\mathrm{z}$ testem Tukeya przy $\alpha<0,05$

Fig. 3. Number of plants (A) and a dry mass of aboveground parts (B) of Chenopodium album growing in the presence of maltodextrin microcapsules with the studied essential oils. The control treatment (open bar) did not contain microcapsules. Bars present a mean value $\pm S E ; n=3$. Different letters indicate significant differences between means at $p<0.05$ according to Tukey post-hoc test

\section{Wnioski / Conclusions}

1. A significant inhibiting effect of MDX and microencapsulated EOs on the initial growth of weeds was confirmed. Among the tested products, the potato MDX was the most inhibitory.

2. Maize was the most tolerant to the microencapsulated EOs, although at the 3-4 leaves stage, there was a significant decrease in the relative chlorophyll content of the leaves. MDX significantly decreased the dry mass of maize roots at the dose of $200 \mathrm{~kg} / \mathrm{ha}$.

3. Lambsquarters was more susceptible to the microencapsulated EOs than barnyard grass, which was mostly reflected as a decrease in the dry mass of the aboveground parts of the plants.

4. Among the microencapsulated EOs, the peppermint oil microcapsules applied at the dose of $200 \mathrm{~kg} /$ ha showed the most inhibitory action against barnyard grass, whilst the caraway oil microcapsules at the dose of $200 \mathrm{~kg} / \mathrm{ha}$ as well affected lambsquarters the most.

\section{Podziękowania / Acknowledgements}

This research was financed by the Ministry of Science and Higher Education of the Republic of Poland (DS 3124). 


\section{Literatura / References}

Arana-Sanchez A., Estarron-Espinosa M., Obledo-Vazquez E.N., Padilla-Camberos E., Silva-Vazquez R., Lugo-Cervantes E. 2010. Antimicrobial and antioxidant activities of Mexican oregano essential oils (Lippia graveolens $\mathrm{H}$. B. K.) with different composition when microencapsulated in b-cyclodextrin. Letters in Applied Microbiology 50 (6): 585-590.

Buttery B.R., Buzzell R.I. 1977. The relationship between chlorophyll content and rate of photosynthesis in soybeans. Canadian Journal of Plant Science 57 (1): 1-5.

Cavalieri A., Caporali F. 2010. Effects of essential oils of cinnamon, lavender and peppermint on germination of Mediterranean weeds. Allelopathy Journal 25 (2): 441-452.

da Costa S.B., Duarte C., Bourbon A.I., Pinheiro A.C., Serra A.T., Moldão Martins M., Nunes Januário M.I., Vicente A.A., Delgadillo I., Duarte C., da Costa B.M.L. 2012. Effect of the matrix system in the delivery and in vitro bioactivity of microencapsulated oregano essential oil. Journal of Food Engineering 110 (2): 190-199.

Del Toro-Sanchez C.L., Ayala-Zavala J.F., Machi L., Santacruz H., Villegas-Ochoa M.A., Alvarez-Parrilla E., Gonzalez-Aguilar G.A. 2010. Controlled release of antifungal volatiles of thyme essential oil from $\beta$-cyclodextrin capsules. Journal of Inclusion Phenomena and Macrocyclic Chemistry 67 (3-4): 431-441.

Gharsallaoui A., Roudaut G., Chambin O., Voilley A., Saurel R. 2007. Applications of spray-drying in microencapsulation of food ingredients: An overview. Food Research International 40 (9): 1107-1121.

Hernández-Hernández E., Regalado-González C., Vázquez-Landaverde P., Guerrero-Legarreta I., García-Almendárez B.E. 2014. Microencapsulation, chemical characterization, and antimicrobial activity of Mexican (Lippia graveolens H.B.K.) and European (Origanum vulgare L.) oregano essential oils. The Scientific World Journal 641814: 1-13. DOI:10.1155/2014/641814.

Kalemba D., Marschall H., Bradesi P. 2001. Constituents of the essential oil of Solidago gigantea Ait. (giant goldenrod). Flavour and Fragrance Journal 16 (1): 19-26.

Katz F.R. 1986. Maltodextrins. Cereal Foods World 31: 866-867.

Nazarro F., Orlando P., Fratianni F., Coppola R. 2012. Microencapsulation in food science and biotechnology. Current Opinion in Biotechnology 23 (2): 182-186.

Ré I.M. 1998. Microencapsulation by spray drying. Drying Technology 16 (6): 1195-1236.

Rolli E., Marieschi M., Maietti S., Sacchetti G., Bruni R. 2014. Comparative phytotoxicity of 25 essential oils on pre- and postemergence development of Solanum lycopersicum L.: A multivariate approach. Industrial Crops and Products 60: 280-290.

Růžek L., Růžková M., Koudela M., Bečková L., Bečka D., Kruliš Z., Šárka E., Voříšek K., Ledvina Š., Šalounová B., Venyercsanová J. 2015. Biodegradation of composites based on maltodextrin and wheat B-starch in compost. Horticultural Science 42: $209-214$.

Scarfato P., Avallone E., De Feo V., Acierno D. 2007. Synthesis and characterization of polyurea microcapsules containing essential oils with antigerminative activity. Journal of Applied Polymer Science 105 (6): 3568-3577.

Soottitantawat A., Yoshii H., Furuta T., Ohkawara M., Linko P. 2003. Microencapsulation by spray drying: influence of emulsion size on the retention of volatile compounds. Journal of Food Science 68 (7): 2256-2262.

StatSoft, Inc. (2011). STATISTICA (data analysis software system), version 10. www.statsoft.com.

Synowiec A., Drozdek E. 2016. Physicochemical and herbicidal properties of emulsions of essential oils against Avena fatua L. and Chenopodium album L. Journal of Plant Diseases and Protection 123 (2): 65-74.

Synowiec A., Kalemba D., Drozdek E., Bocianowski J. 2016. Phytotoxic potential of essential oils from temperate climate plants against the germination of selected weeds and crops. Journal of Pest Science 1-13. DOI:10.1007/s10340-016-0759-2.

Terzi I. 2008. Allelopathic effects of juglone and decomposed walnut leaf juice on muskmelon and cucumber seed germination and seedling growth. African Journal of Biotechnology 7 (12): 1870-1874.

Varona S., Rojoa S.R., Martína Á., Coceroa M.J., Serrab A.T., Crespob T., Duarte C.M.M. 2013. Antimicrobial activity of lavandin essential oil formulations against three pathogenic food-borne bacteria. Industrial Crops and Products 42: 243-250. 